\title{
ОСНОВНІ КОМПОНЕНТИ ТА ШЛЯХИ ФОРМУВАННЯ КОМУНІКАТИВНОЇ ГОТОВНОСТІ СТУДЕНТІВ НЕЛІНГВІСТИЧНИХ ЗАКЛАДІВ ВИЩОЇ ОСВІТИ ДО ОВОЛОДІННЯ ІНОЗЕМНОЮ МОВОЮ
}

\author{
Рідель Т. М. \\ кандидат педагогічних наук, доиент, \\ доиент кафедри іноземних мов \\ Сумський національний аграрний університет \\ вул. Г. Кондратьєва, 160, Суми, Украӥна \\ orcid.org/0000-0002-6980-7975 \\ tridel@ukr.net
}

Кириченко Т. О.

кандидат економічних наук, старший викладач кафедри іноземних мов

Сумський національний аграрний університет

вул. Г. Кондратьєва, 160, Суми, Україна

orcid.org/0000-0002-9160-2124

honey11t@ukr.net

Ключові слова: професійна підготовка, вивчення іноземної мови, міжкультурна комунікація, комунікативні якості особистості, подолання труднощзів, рівні володіння мовою.
Статтю присвячено розкриттю змісту поняття «комунікативна готовність студентів нелінгвістичних закладів вищої освіти до оволодіння іноземною мовою» та складників такої готовності, а також дослідженнюособливостейїіформування. Крімцього, наданорезультати теоретичного обгрунтування та практичної розробки проблеми подолання труднощів під час вивчення іноземної мови студентами нелінгвістичних 3ВО на основі системного підходу. Відзначено, що сучасний соціум потребує особистості полікультурного типу, яка здатна та готова ефективно взаємодіяти у глобальному полікультурному просторі. Визначено, що комунікативна готовність - це інтегративна та динамічна якість майбутнього спеціаліста. Проаналізовано, що формування комунікативної готовності студентів до ефективного оволодіння іноземною мовою $є$ процесом цілеспрямованого, комплексного та якісного перетворення особистості. Уточнено визначення та специфічні особливості формування комунікативної готовності студентів до оволодіння іноземною мовою. 3 цього приводу охарактеризовано компоненти комунікативної готовності, до яких віднесено мотиваційний (спрямований на стимулювання та підтримку комунікативної активності студентів у процесі міжкультурної взаємодії), особистісний (включає систему індивідуальних установок у сфері міжособистісного спілкування, моральні цінності, комунікативні якості особистості, що характеризують потребу в спілкуванні, ставлення до способу спілкування), когнітивний (лінгво-креативне мислення, що визначає мовно-розумові здатності особистості, знання і досвід у галузі міжкультурної комунікації), емоційноціннісний (емоційний позитивний настрій i емоційна готовність особистості до міжкультурної комунікації сприятимуть швидкій іiі акультурації) і діяльнісний (включає комунікативні засоби, іншомовну комунікативну компетенцію і соціокультурні якості), а також основні види комунікативних труднощів під час вивчення іноземної мови. 
Запропонована модель формування комунікативної готовності до оволодіння іноземною мовою та надано результати дослідницько-експериментальної роботи з перевірки ефективності цієї моделі формування комунікативної готовності. У результаті дослідження було виявлено, що подолання комунікативних труднощів, що виникають у процесі вивчення іноземної мови у студентів нелінгвістичних спеціальностей, може відбуватися на різних рівнях: початковому, операційному, технічному. Кожен із зазначених рівнів наповнений своїм змістом і основними критеріальними ознаками.

\title{
BASIC COMPONENTS AND WAYS OF FORMATION OF FOREIGN-LANGUAGE COMMUNICATIVE COMPETENCE OF NON-PHILOLOGICAL TRAINING PROFILE STUDENTS
}

\author{
Ridel T. M. \\ Candidate of Pedagogical Sciences, Associate Professor, \\ Associate Professor at the Department of Foreign Languages \\ Sumy National Agrarian University \\ H. Kondratieva str., 160, Sumy, Ukraine \\ orcid.org/0000-0002-6980-7975 \\ tridel@ukr.net
}

Kyrychenko T. O.

Candidate of Economic Sciences, Senior Lecturer at the Department of Foreign Languages

Sumy National Agrarian University

H. Kondratieva str., 160, Sumy, Ukraine

orcid.org/0000-0002-9160-2124

honey11t@ukr.net

Key words: professional training, learning a foreign language, intercultural communication, communicative personality traits, overcoming difficulties, levels of language proficiency.
The article is devoted to the disclosure of the concept of communicative readiness of non-philological training profile students to master a foreign language and its components, as well as to study the peculiarities of its formation. In addition, the results of theoretical substantiation and practical development of the problem of overcoming difficulties in learning a foreign language by non-philological training profile students based on a systematic approach are provided. It is noted that modern society needs a personality of the multicultural type, which is able and ready to interact effectively in the global multicultural space. It is determined that communicative readiness is an integrative and dynamic quality of a future specialist. It is analyzed that the formation of students' communicative readiness for effective mastery of a foreign language is a process of purposeful, comprehensive and high-quality transformation of personality. The definitions and specific features of the formation of students' communicative readiness to master a foreign language are specified. In this regard, the components of communicative readiness are characterized, which include motivational (aimed at stimulating and supporting communicative activity of students in the process of intercultural interaction), personal (includes a system of individual attitudes in interpersonal communication, moral values, communicative personality traits), cognitive (lingo-creative thinking, which determines the linguistic and mental abilities of the individual, knowledge and experience in the field of intercultural communication), emotional-value (emotional positive mood and emotional readiness of the individual for intercultural communication will contribute to its rapid acculturation) and activity component (includes communication 
tools, foreign language communication competence and socio-cultural qualities), as well as the main types of communication difficulties in learning a foreign language. The model of formation of communicative readiness for mastering a foreign language is offered and the results of research and experimental work on checking the effectiveness of this model of formation of communicative readiness are given. As a result of the research it was found that overcoming communicative difficulties that arise in the process of learning a foreign language by nonphilological training profile students can occur at different levels: primary, operational, technical. Each of these levels is filled with its own content and basic criteria.

Постановка проблеми. У сучасному суспільстві значно збільшилася кількість ситуацій, видів і форм діяльності, для здійснення яких необхідне володіння компете нціями іншомовного усного та письмового спілкування. Дослідниками виявлено значні відмінності в затребуваності конкретних іншомовних мовних компетенцій, що визначаються сферою діяльності фахівця, а також у необхідних рівнях володіння такими компетенціями. Все це визначає потребу сучасного соціуму в особистості полікультурного типу, здатної і готової ефективно взаємодіяти у глобальному полікультурному просторі.

Наявні дослідження, що відображають особливості навчання іноземної мови молоді (С. Ніколаєва, О. Бігич, Н. Бориско, Г. Борецька).

Проблеми та особливості професійної іншомовної підготовки фахівців негуманітарного профілю відображені у працях П. Беха, Н. Бібік, І. Бім, С. Гончаренка, І. Зимньої, С. Ніколаєвої, С. Кожушко, О. Леонтьєва, С. Пассова, О. Тарнопольського.

Аналіз наукових джерел свідчить, що проблема формування комунікативної компетенції була i $є$ предметом розгляду українських (Л. Бірюк, А. Богуш, Т. Вольфовська, С. Ніколаєва, О. Павленко, Л. Паламар, М. Пентилюк) і зарубіжних (М. Вятютнєв, Н. Гальскова, Н. Гез, В. Коккота, О. Леонтьєв, Р. Мільруд, О. Миролюбов, А. Немушин, Ю. Пассов, L. Bachman, M. Canale, D. Hymes, A. Holliday, M. Swain) психологів, лінгвістів, педагогів, оскільки йдеться про підготовку спеціалістів.

Способи оцінки якості підготовки фахівця нового типу і вдосконалення процесу управління розглядаються в роботах українських науковців В. Гладкової, С. Пожарського, В. Загорського і зарубіжних Є. Яковлєва, Н. Бірюкової, О. Кузьменко та ін.

Мета статті. Особливу значущість натепер набувають питання розробки оптимальної освітньої моделі, створення навчально-методичних ресурсів, спрямованих на ефективне формування комунікативної готовності студентів нелінгвістичних спеціальностей відповідно до сучасних вимог держави в галузі якості вищої професійної освіти. Крім того, це також зумовлене потребами самої особистості, суспільства і роботодавців. Ставимо за мету розглянути комунікативну готовність студента як інтегративну та динамічну якість майбутнього спеціаліста; уточнити визначення та специфічні особливості формування комунікативної готовності студентів до оволодіння іноземною мовою; охарактеризувати компоненти комунікативної готовності, а також основні види комунікативних труднощів під час вивчення іноземної мови; надати результати дослідницько-експериментальної роботи з перевірки ефективності розробленої моделі формування комунікативної готовності.

Виклад основного матеріалу дослідження. Більшість учених мають спільну думку, що професійно-орієнтоване іншомовне спілкування відрізняється від інших видів спілкування перш за все тим, що учасники комунікації представляють різні культури і соціуми. Аналіз останніх досліджень дозволив нам визначити іншомовне мовлення як інтегративне особистісно-професійне утворення, яке реалізується у психологічній та технічно-операційній готовності особистості до виконання успішної, продуктивної та ефективної професійної діяльності 3 використанням засобів іноземної мови або в умовах іншомовної культури та забезпечує можливість ефективної взаємодії 3 навколишнім середовищем. Мовленнєва компетенція особистості реалізується у виконанні різних видів мовленнєвої діяльності, а саме сприймання, усвідомлення, відтворення (усне чи письмове) [6].

Таким чином, професійно-орієнтоване іншомовне спілкування передбачає таку організацію мовленнєвої взаємодії, яка повинна забезпечувати продуктивний контакт фахівця з учасниками професійної діяльності, що стає можливим у разі знання культурних особливостей співрозмовника i коректного стилю поведінки. Такої точки зору дотримуються Н. Гез і Н. Гальскова. Вони вважають, що результат іншомовної освіти полягає в розвитку мовної особистості, що видається можливим, якщо навчання іншомовного спілкування відбувається в контексті діалогу культур. Учені трактують мовну особистість як «багатокомпонентний набір мовних здібностей, умінь, готовностей до здійснення мовних вчинків різного ступеня складності, вчинків, які класифікуються за видами мовленнєвої діяльності і за рівнями мови» [1, с. 21]. 
Принцип співтворчості, творчого саморозвитку і самореалізації, що впливає на формування мотиваційного та діяльнісного компонентів комунікативної готовності, дозволяє затвердити у спілкуванні викладача і студентів таку оптимальну форму їхньої взаємодії, як діалог, сутність якого полягає у взаємному збагаченні та особистісному розвитку його учасників. Цей процес $\epsilon$ суб' єкт-суб'єктною взаємодією викладача і студента як партнерів. Студент стає співавтором навчальної діяльності, яку творчо організовує викладач. Узагальнюючи теоретико-методологічні дослідження 3 проблеми розвитку комунікативної готовності студентів нелінгвістичних спеціальностей до оволодіння іноземною мовою, вважаємо, що сутність процесу формування комунікативної готовності до оволодіння іноземною мовою полягає в удосконаленні особистісних $\mathrm{i}$ професійних якостей, а також підвищенні рівня знань, умінь і ключових компетенцій, необхідних студентам для успішного оволодіння іноземною мовою.

Ми поділяємо точку зору авторів, що визначають комунікативну готовність як інтегральне утворення, що складається 3 декількох груп характеристик (Л. Гейхман, М. Молчановський). У цьому разі зміст поняття «комунікативна готовність» розкривається через обгрунтування його основних компонентів - мотиваційного, особистісного, когнітивного, емоційно-ціннісного і діяльнісного.

У працях українських та зарубіжних психологів відзначається домінуюча роль мотиваційних явищ у психічній діяльності кожної людини i ïx вирішальне значення в професійній підготовці фахівців. Керуючись цими положеннями, нами було виділено як один 3 компонентів комунікативної готовності мотиваційний, спрямований на стимулювання та підтримку комунікативної активності студентів у процесі міжкультурної взаємодії. Він є також сукупністю причин психологічного характеру, що пояснюють сам акт спілкування, його початок, спрямованість і активність.

Грунтуючись на наукових працях, доходимо висновку, що цей компонент комунікативної готовності містить спрямованість суб'єкта на демонстрацію такої якості 3 метою підвищення ефективності взаємодії з представниками інокультури, що виражається у спонукальних формах мотивах, потребах, цілях, інтересах, прагненнях і в перцептивних формах - цінностях, життєвих принципах, ціннісних орієнтаціях.

За логікою наших міркувань та керуючись структурою психіки, таким компонентом комунікативної готовності нами виділено емоційно-ціннісний. Емоції - це переживання людиною ставлення до навколишнього світу і до самої себе; деякі специфічні фізіологічні та психологічні стани або процеси; засоби, за допомогою яких взаємодіють тіло і розум. На підставі досліджень доходимо висновку, що емоційне позитивне налаштування i емоційна готовність особистості до міжкультурної комунікації сприятимуть швидкій іiі акультурації, що дозволить індивіду бути готовим до взаємодії 3 представниками іншої лінгвокультури. Можна виділити емоційні стани, що провокують труднощі комунікації: напруженість, почуття тривоги, страху, самотності і неповноцінності, почуття самоідентифікації і т.ін., які утворюють у комуніканта стан «культурного шоку» [3; 4].

Отже, ми розглядаємо емоційний компонент у рамках цього дослідження як позитивне емоційне налаштування на міжкультурну комунікацію, емоційну культуру, емоційний інтелект і емоційну креативність, що дозволяють долати «культурний шок», швидко адаптуватися і мобілізуватися в нових ситуаціях, контролювати свої емоції, не проявляти агресію в процесі міжкультурної взаємодії.

Наступним компонентом у структурі комунікативної готовності до оволодіння іноземною мовою виділяємо когнітивний. Когнітивну сторону готовності вивчали багато зарубіжних учених, досліджуючи структуру дивергентного мислення (С. Канн, J. Guilford, S. Mednich, E. Torrance i iн.), характеристики та психологічні механізми інтелектуальної обдарованості (А. Матюшкін, М. Холодна та ін.), інтелектуальну активність (Д. Богоявленська) тощо. На підставі проведеного аналізу наукових праць з цісї проблеми нами включені до складу когнітивного компонента комунікативної готовності: лінгво-креативне мислення, що визначає мовно-розумові здатності особистості, знання і досвід у галузі міжкультурної комунікації.

Наступним компонентом комунікативної готовності нами виділено діяльнісний, заснований на положеннях поведінкового підходу. Він містить низку технологій і компетенцій, необхідних для реалізації цього феномена в оволодінні іноземною мовою.

Діяльнісний компонент комунікативної готовності студента, що включає комунікативні засоби, іншомовну комунікативну компетенцію і соціокультурні якості, відповідає за зв'язність і послідовність мовних висловлювань, за адекватність поведінки і ефективне використання комунікативних, управлінських стратегій і тактик співробітництва, що забезпечують безконфліктну, адекватну гуманістичним цілям комунікацію 3 представниками інокультури.

Особистісний компонент комунікативної готовності до оволодіння іноземною мовою включає систему індивідуальних установок у сфері 
міжособистісного спілкування, моральні цінності, комунікативні якості особистості, що характеризують потребу в спілкуванні, ставлення до способу спілкування.

Комунікативно-особистісні проблеми, що виникають під час навчання іноземної мови, можна класифікувати як:

- мотиваційно-ціннісні (відсутність інтересу до вивчення іноземної мови, слабкий стимул до навчання і розвитку);

- когнітивні (труднощі сприйняття, запам'ятовування, розуміння матеріалу, інтелектуально-комунікативні порушення);

- емоційно-регулятивні (підвищена емоційність, недостатній самоконтроль, підвищений рівень тривожності);

- характерологічні (переважання негативних якостей характеру, що ускладнюють спілкування і встановлення позитивних відносин у групі);

- комунікативно-мовні (утруднення у вербальному вираженні думок і почуттів, встановлення контакту з оточуючими);

- духовні (відсутність або слабка вираженість загальнолюдських чеснот і ціннісних орієнтацій).

Комунікативна готовність студента нелінгвістичної спеціальності до оволодіння іноземною мовою розглядається нами як інтегративна i динамічна якість майбутнього фахівця, що припускає наявність елементарного рівня знання іноземної мови, активну включеність у процес iii вивчення, знання норм комунікативної поведінки. Внутрішньоособистісними якостями тут $\epsilon$ комунікативна активність (інтенсивність комунікативної діяльності, спрямованої на побудову стійких взаємин, iï операційно-динамічні характеристики), комунікативна рефлексія (усвідомлення студентом комунікативних особливостей своєї особистості, власних почуттів, думок, дій, а також усвідомлення того, яким сприймають його оточуючі).

У разі комунікативного підходу особливе значення надається змістовій стороні мови, ii впливу на партнера, реалізації всіх основних функцій спілкування: пізнавальної, ціннісно-орієнтаційної, регулятивної і конвенційної. Відповідно, у разі комунікативно-орієнтованого навчання майбутніх фахівців іноземних мов кінцевою метою $\epsilon$ формування у студентів комунікативної компетенції, що включає різні компоненти: лінгвістичну компетенцію (готовність використовувати іноземну мову як знаряддя мовленнєво-розумової діяльності), прагматичну компетенцію (готовність передавати комунікативний зміст у ситуації спілкування), когнітивну компетенцію (готовність до комунікативно-розумової діяльності) та інформативну компетенцію (володіння змістовним предметом спілкування).
У рамках нашого дослідження моделювання процесу формування комунікативної готовності до оволодіння іноземною мовою у студентів нелінгвістичних спеціальностей спрямовано на виділення блоків, кожен 3 яких виконує певну функцію: виявлення суперечностей і визначення задуму дослідження; уявлення теоретико-методологічних підходів і принципів розвитку цього феномена; вивчення сутності, змістового наповнення компонентів комунікативної готовності i педагогічних умов; організації ефективного розвитку комунікативної готовності студентів закладу вищої освіти (етапи, технології, методи, прийоми, форми, засоби); виділення критеріїв і показників і підбір діагностичних методик для оцінки рівня іiі розвитку у студентів і коригування програми їх навчання.

Метою дослідно-експериментальної роботи стала перевірка ефективності моделі формування комунікативної готовності до оволодіння іноземною мовою у студентів нелінгвістичних спеціальностей у разі реалізації комплексу виявлених педагогічних умов.

Критеріями виявлення успішності чи неуспішності формування комунікативної готовності у студентів нелінгвістичних спеціальностей у процесі вивчення іноземної мови можна назвати такі як: формальна успішність; можливість використання мов студентами в різних контекстних ситуаціях; ступінь включеності в процес вивчення іноземної мови; емоційний стан студентів, які засвоюють нову мовну реальність; самооцінка студентів.

В експерименті брали участь 150 студентів, 3 них безпосередніми учасниками формуючого етапу експерименту стали 120 осіб, а в експериментальну групу увійшли 60 осіб.

У ході аналізу було виявлено, що більшість піддослідних перебувають на початковому рівні подолання комунікативних труднощів, тобто на рівні, який відрізняє нестійкість якості знань i умінь 3 предмета «Іноземна мова», неясно виражений професійний намір щодо її застосування; відсутність комунікативної готовності до подолання труднощів (агресивність, дратівливість, суб'єктивне відчуття самотності, тривожність); свідоме ставлення до своєї професійної діяльності; несформованість самоуправління.

Віднесення до певного рівня (початкового, операційного, технічного) на констатуючому етапі експерименту проводилося за допомогою діагностики зміни станів прояву комунікативних труднощів. Середній бал, що знаходиться в проміжку від 2 до 3,3 б., співвідносить рівень сформованості до початкового (I); середній бал, що знаходиться в проміжку від 3,3 до 4,2 б., - до операційного (II); середній бал, що знаходиться в проміжку від 4,2 до 5 б., - до технічного (III). Для контролю знань 
студентів використовувалися тести, тому що саме тести припускають більш часту систематизовану і об'єктивну перевірку знань. Перевірка розуміння науково-технічного тексту включає тестування уміння виділяти графічну інформацію, пов'язану 3 оволодінням графічною системою мови: структурну інформацію, під якою розуміється граматика і словотвір, і семантичну інформацію, тобто зміст тексту. Основними параметрами тестів $є$ їх дієвість і надійність. Результати тестування показали, що тести дають можливість об'єктивно виявити рівень сформованості вмінь, виділених як об'єктів тестування. Тестові оцінки стимулюють навчальну діяльність студентів. Отримувані оцінки об'єктивні і реально оцінюють знання студентів.

Таким чином, науковий відбір навчального матеріалу, його комплексна методична організація, розвиток логічного мислення студентів, теоретичне узагальнення накопичених знань, тестування - все це сприяє більш якісному та ефективному професійно-орієнтованому навчанню студентів нелінгвістичних спеціальностей.

Загалом про групи студентів, які брали участь в експерименті, отримані дані відображені в таблиці 1.

Таблиця 1

Показники вираженості рівнів сформованості комунікативної готовності до оволодіння іноземною мовою у студентів нелінгвістичних спеціальностей на констатуючому етапі експерименту

\begin{tabular}{|c|c|c|c|c|c|c|c|}
\hline \multirow{3}{*}{ 袙 } & \multirow{3}{*}{ 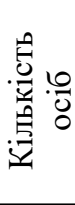 } & \multicolumn{6}{|c|}{ Рівні } \\
\hline & & \multicolumn{2}{|c|}{$\begin{array}{c}\text { I } \\
\text { початковий }\end{array}$} & \multicolumn{2}{|c|}{$\begin{array}{c}\text { II } \\
\text { опера- } \\
\text { ційний }\end{array}$} & \multicolumn{2}{|c|}{$\begin{array}{c}\text { III } \\
\text { технічний }\end{array}$} \\
\hline & & К-ть & $\%$ & К-ть & $\%$ & К-ть & $\%$ \\
\hline $\mathrm{K} \Gamma$ & 60 & 26 & 43,3 & 24 & 40 & 10 & 16,7 \\
\hline $\mathrm{E} \Gamma$ & 60 & 25 & 41,7 & 24 & 40 & 11 & 18,3 \\
\hline
\end{tabular}

Аналіз отриманих експериментальних даних дозволяє зробити такий висновок. Якщо не ставити за мету формування комунікативної готовності до оволодіння іноземною мовою у студентів нелінгвістичних спеціальностей, яке передбачає раціональний підхід до будь-яких видів діяльності і центрацію на себе як суб'єкта діяльності і спілкування; наявність постійної рефлексії щодо себе, своїх здібностей і можливостей; контрольованих проявів товариськості і екстраверсії; добре контрольовані цілі і мотиви діяльності, то ефективне оволодіння необхідними знаннями, вміннями і навичками у вивченні іноземної мови не відбувається [2].

На формуючому етапі експерименту студенти взаємодіяли і допомагали один одному, що акту- ально в контексті іншомовного професійного навчання в групах студентів з різним початковим рівнем володіння мовою. Традиційні практичні заняття проводилися в активному, діяльнісному режимі, використовувалися різні форми роботи (індивідуальна, парна, фронтальна, групова). Процес реалізації педагогічної моделі формування комунікативної готовності до оволодіння іноземною мовою у студентів нелінгвістичних спеціальностей включав взаємопов'язані етапи: комплексний аналіз особистості; використання потрібного технологічного інструментарію; виключення небажаних стереотипів, ціннісних орієнтацій, мотивів поведінки, закріплення досягнутих результатів; занурення суб'єкта освітнього процесу в певну систему вправ, фіксування у свідомості суб'єкта духовних цінностей і манер поведінки; створення низки альтернативних проблемних ситуацій, які надають суб'єкту можливість для демонстрації зміненої поведінки [3], в рамках цього дослідження - подолання комунікативних труднощів.

Для перевірки ефективності моделі дійового формування комунікативної готовності до оволодіння іноземною мовою у студентів нелінгвістичних вузів нами була проведена повторна діагностика випробовуваних.

Аналіз результатів дослідження видів спрямованості особистості за методикою «Визначення спрямованості особистості» (Б. Басса) показав, що спрямованість на себе (Я) виявили $31,7 \%$ випробовуваних КГ і 8,3\% ЕГ. Спрямованість на спілкування (Сп) продемонстрували 43,3\% студентів КГ та 40\% ЕГ. Спрямованість на справу (Спр) є пріоритетом для 25\% випробовуваних КГ i 51,7\% ЕГ. Дані свідчать про досить стабільну позитивну динаміку в ЕГ: кількість випробовуваних, які спрямовані на себе (Я), зменшилася в 4 рази; кількість випробовуваних, які спрямовані на спілкування (Сп), збільшилася на 1,7\%; кількість випробовуваних, які спрямовані на справу (Спр), зросла у 2 рази. Це дозволяє зробити висновок про прагнення студентів нелінгвістичних спеціальностей реалізувати знання іноземної мови в процесі спілкування, що своєю чергою свідчить про подолання труднощів спілкування в іншомовній реальності.

Показники багатофакторного особистісного опитувальника FPI [5] дозволяють судити про те, що в ЕГ показники таких станів і властивостей особистості у разі виникнення труднощів у вивченні іноземної мови: депресивність, товариськість, сором'язливість, емоційна лабільність - істотно змінилися (в 2 рази знизилися). Поряд 3 цим зазначаємо позитивну динаміку в емоційному стані, в поведінці, у ставленні до себе. У піддослідних усунена схильність до стресового реагування на звичайні ситуації в процесі 
іншомовного спілкування. На етапі формуючого експерименту у студентів ЕГ виробилася впевненість у собі, життєва активність і оптимістичне ставлення до навколишньої дійсності, що безпосередньо свідчить про сформованість засобів захисту до впливу стрес-факторів у вивченні іноземної мови.

Аналіз результатів рівнів вираженості показників самооцінки у студентів нелінгвістичного закладу вищої освіти показав, що самооцінка висока неадекватна стала характеризувати $11,7 \%$ випробуваних у КГ і 3,3\% в ЕГ, самооцінка висока адекватна - $25 \%$ у КГ та $16,7 \%$ в ЕГ, самооцінка середня адекватна властива $48,3 \%$ випробуваних у КГ і $68,3 \%$ в ЕГ, самооцінка низька адекватна $8,3 \%$ у КГ та $10 \%$ в ЕГ, самооцінка низька неадекватна у $6,7 \%$ у КГ і $1,7 \%$ в ЕГ.

Результати формуючого експерименту виявили позитивну динаміку формування комунікативної готовності до оволодіння іноземною мовою у студентів експериментальної групи (таблиця 2). Початковий рівень (I) знизився на $38,4 \%$. Операційний рівень (II) не знизився $(-1,7 \%)$, технічний (III) підвищився на 40,1\%.

Таблиця 2

Показники вираженості рівня комунікативної готовності до оволодіння іноземною мовою у студентів нелінгвістичних спеціальностей на підсумковому етапі експерименту

\begin{tabular}{|c|c|c|c|c|c|c|c|}
\hline \multirow{3}{*}{ 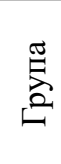 } & \multirow{3}{*}{ 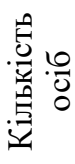 } & \multicolumn{6}{|c|}{ Рівні } \\
\hline & & \multicolumn{2}{|c|}{$\begin{array}{c}\mathrm{I} \\
\text { початковий }\end{array}$} & \multicolumn{2}{|c|}{$\begin{array}{c}\text { II } \\
\text { операційний }\end{array}$} & \multicolumn{2}{|c|}{$\begin{array}{c}\text { III } \\
\text { технічний }\end{array}$} \\
\hline & & К-ть & $\%$ & К-ть & $\%$ & К-ть & $\%$ \\
\hline КГ & 60 & 12 & 20 & 35 & 58,3 & 13 & 21,7 \\
\hline $\mathrm{E} \Gamma$ & 60 & 2 & 3,3 & 23 & 38,3 & 35 & 58,4 \\
\hline
\end{tabular}

Висновки. Таким чином, у результаті проведеного формуючого етапу експерименту ми дійшли таких висновків.

У ході експериментального дослідження здійснено відстеження динаміки в переході студента нелінгвістичного закладу вищої освіти 3 початкового рівня сформованості комунікативної готовності до оволодіння іноземною мовою на операційний і технічний.

Специфіка демонстрації комунікативних труднощів, що виникають у процесі вивчення іноземної мови у студентів нелінгвістичних спеціальностей, полягає у значній кореляції прояву труднощів 3 депресивністю, дратівливістю, суб' єктивним відчуттям самотності, тривожністю. Діагностика динаміки сформованості подолання комунікативних труднощів виявила усунення значущих проявів емоційних станів за допомогою реалізації моделі формування комунікативної готовності до оволодіння іноземною мовою. Результати формуючого етапу експерименту продемонстрували помітне підвищення рівня сформованості комунікативної готовності до оволодіння іноземною мовою у студентів нелінгвістичних спеціальностей. Найбільш виражені зміни спостерігаються в експериментальній групі, де технічний рівень названої сформованості зріс на 40,1\%. У контрольній групі, де в процесі проведення експерименту не здійснювалося використання моделі формування комунікативної готовності, технічний рівень підвищився лише на 5\%.

Аналіз результатів дослідно-експериментальної роботи виявив, що подолання комунікативних труднощів, що виникають у процесі вивчення іноземної мови у студентів нелінгвістичних спеціальностей, може відбуватися на різних рівнях: початковому, операційному, технічному. Кожен iз зазначених рівнів наповнений своїм змістом $\mathrm{i}$ основними критеріальними ознаками.

\section{ЛІТЕРАТУРА}

1. Гальскова Н.Д., Никитенко 3.Н. О взаимодействии учителя и учащихся на уроке иностранного языка. Иностранный язык в школе. 1991. № 1. С. 20-22.

2. Камянова Т.Г. Системный подход как новый метод повышения качества изучения иностранных языков. Качество. Инновачии. Образование. 2009. № 1. С. $23-27$.

3. Нурмухамбетова С.Н. Проблемы формирования коммуникативной готовности к овладению иностранным языком у студентов неязыковых специальностей. Общество: сочиология, психология, педагогика. 2016. № 2 (февраль). С. 167-172.

4. Прохорова Т.Н., Григорьева М.А. Специфика учебного взаимодействия преподавателя иностранного языка и студента в контексте обоюдного личностно-творческого самоопределения. Вестник РУДН. Серия «Психология и педагогика». 2013. № 3. С. 123-129.

5. Тест FPI. Фрайбургский многофакторный личностный опросник. Методика исследования личности. URL: https://psycabi.net/testy/462-test-fpi-frajburgskij-mnogofaktornyj-lichnostnyj-oprosnik-metodika-issledovaniya-lichnosti.

6. Чиханцова О.А. Значення іншомовного професійного спілкування для студентів немовних ВНЗ. Актуальні проблеми навчання та виховання людей з особливими потребами. 2015. № 12 (14). C. $127-142$. 


\section{REFERENCES}

1. Halskova, N.D., Nikitenko Z.N. (1991). O vzaimodeistvii uchitelia i uchashchikhsia na uroke inostrannoho yazyka [On the interaction of teacher and students during a foreign language lesson]. Foreign language at school. Vol. 1. P. 20-22.

2. Kamianova, T.H. (2009). Sistemnyy podkhod kak novyy metod povysheniya kachestva izucheniya inostrannykh yazykov [Systematic approach as a new method for improving the quality of learning foreign languages]. Quality. Innovation. Education. Vol. 1. P. 23-27.

3. Nurmykhambetova, S.N. (2016). Problemy formirovaniya kommunikativnoy hotovnosti k ovladeniyu inostrannym yazykom u studentov neyazykovykh spetsialnostey [Problems of communicative readiness formation for mastering a foreign language among students of non-linguistic specialties]. Society: sociology, psychology, pedagogy. Vol. 2. P. 167-172.

4. Prokhorova, T.N., Hrihorieva M.A. (2013). Spetsifika uchebnoho vzaimodeystviya prepodavatelia inostrannoho yazyka i studenta $\mathrm{v}$ kontekste oboyudnoho lichnostno-tvorcheskoho samoopredeleniya [Specifics of educational interaction between a foreign language teacher and a student in the context of mutual personal and creative self-determination]. RUDN Bulletin. Psychology and Pedagogy series. Vol. 3. P. 123-129.

5. Test FPI. Fraiburhskiy mnohofaktornyy lichnostnyy oprosnik. Metodika issledovaniya lichnosti [FPI test. Freiburg multivariate personality questionnaire. Personality research methodology]. URL: https://psycabi.net/testy/462-test-fpi-frajburgskij-mnogofaktornyj-lichnostnyj-oprosnik-metodikaissledovaniya-lichnosti.

6. Chykhantsova, O.A. (2015). Znachennia inshomovnoho profesiinoho spilkuvannia dlia studentiv nemovnykh VNZ [The importance of foreign language professional communication for students of nonlinguistic universities]. Current problems of education and upbringing of people with special needs. Vol. 12 (14). P. 127-142. 